\title{
PENGARUH KINERJA KEUANGAN TERHADAP HARGA SAHAM PADA PERUSAHAAN CONSUMER GOODS YANG TELAH GO PUBLIC DI BURSA EFEK INDONESIA
}

\author{
Setyaningsih \\ Salamatun Asakdyah \\ Universitas Ahmad Dahlan
}

\begin{abstract}
ABSTRAK
This research aimed to examine the effect of tha financial performance of the stock price. Company that the sample is a consumer goods company that has gone public listed on the Indonesia Stock Exchange 2006-2010 period by 30 companies. The dependent variable used is the stock price while the independent variable is Return On Equity (ROE), Net Profit Margin (NPM), Debt to Equity Ratio (DER) and Earning Per Share (EPS). In this study using a multiple regression test, $t$ test, and classical assumption. Assessment of the effect of independent variable on the dependent variable was partially and using the classical assumption test for normality, multicollinearity, heteroscedasticity, and autocorrelation. The research using multiple regression test showed that the Net Profit Margin (NPM) and Debt to Equity Ratio (DER) has a probability of 0.0715 , respectively, and 0.4396 at a significance level of 0.05 (5\%), both variables no significant effect on stock prices. While Return on Equity (ROE) and Earning Per Share (EPS) have respective probabilities 0.0000 and 0.0000 at tha significant level of 0.05 (5\%), than two variables significant effect on stock prices because the probability of $0.001<0.05$. The coefficient of determination ( $R$ square) is equal to 0.847 . this means that the ability of the four independent variables explained $84.7 \%$ of the dependent variable. And of the results of the classical assumption states that the problem of test for normality and heteroscedasticity test, whereas the multicollinearity test and autocorrelation test no problems.
\end{abstract}

Keywords: Stock Price, Return On Equity, Net Profit Margin, Debt to Equity Ratio and Earning Per Share.

\section{PENDAHULUAN}

Perkembangan perekonomian suatu negara dapat diukur dengan berbagai cara salah satunya adalah dengan mengetahui tingkat perkembangan dunia pasar modal dan industriindustri sekuritas yang ada pada negara tersebut. Pasar modal merupakan salah satu cara yang dapat digunakan untuk memperoleh dana, baik dari dalam maupun dari luar negeri. Kehadiran pasar modal memperbanyak pilihan sumber dana bagi perusahaan serta menambah pilihan investasi, yang dapat juga diartikan kesempatan untuk memperoleh tambahan dana bagi perusahaan semakin besar.

Setiap perusahaan merupakan kesatuan entitas antara pengelola perusahaan (manajemen) dengan pihak-pihak yang berkepentingan dengan perusahaan (Stockholder). Salah satu dari stockholder adalah pemegang saham. Para pemegang saham sebagai pihak yang menginvestasikan sumber daya tentunya 
ingin memperoleh nilai yang paling ekonomis atas investasinya. Para investor yang akan berinvestasi dalam bentuk saham memerlukan informasi-informasi akurat sabagai bahan pertimbangan dalam menentukan pilihan. Selain itu, perkembangan posisi keuangan mempunyai arti yang sangat penting bagi perusahaan.

Alat ukur utama untuk mengevaluasi kinerja keuangan perusahaan dalam kegiatan investasi yang umum digunakan oleh investor adalah rasio profitabilitas sesuai dengan penjelasan oleh Helfert dalam Sihombing (2010), "Daya tarik utama bagi pemilik-pemilik pemegang saham terletak pada profitabilitas yang menunjukkan hasil pengelolaan manajemen perusahaan atas dana yang diinvestasikan". Investor akan cenderung memilih berinvestasi dalam perusahaan yang memiliki rasio profitabilitas dan rasio leverage yang berada di atas atau setara dengan rata-rata industri dan berakibat pada kenaikan harga saham perusahaan tersebut.

Untuk mengukur apakah keuangan suatu perusahaan itu baik, dilakukan sebuah analisis yang biasa disebut dengan analisis rasio keuangan. Untuk melakukan analisis rasio keuangan, diperlukan perhitungan rasio-rasio keuangan yang mencerminkan aspek-aspek tertentu. Dalam penelitian ini menggunakan rasio profitabilitas yaitu Return On Equity, Net Profit Margin, dan rasio leverage yaitu Debt to Equity Ratio, serta rasio pasar yaitu Earning Per Share.

Penelitian-penelitian terdahulu yang telah membuktikan pentingnya kinerja keuangan terhadapharga sahampadaperusahaan diantaranya Halim dalam Sihombing (2010), melakukan penelitian tentang pengaruh ROE, EPS, dan DER terhadap harga saham perusahaan industri manufaktur yang terdaftar di BEI. Penelitian ini bertujuan untuk mengetahui (1) pengaruh yang signifikan antara return on equity terhadap harga saham perusahaan industri manufaktur yang terdaftar di BEI; (2) pengaruh yang signifikan antara earning per share terhadap harga saham perusahaan industri manufaktur yang terdaftar di BEI; (3) pengaruh yang signifikan antara debt to equity ratio terhadap harga saham pada perusahaan industri manufaktur yang terdaftar di BEI; (4) pengaruh yang signifikan secara bersama-sama antara ROE, EPS dan DER terhadap harga saham perusahaan industri manufaktur yang terdaftar di BEI. Metode pengumpulan data menggunakan metode studi pustaka, atau pengumpulan data dari Bursa Efek Jakarta. Teknik analisis data menggunakan analisis regresi linier berganda, uji-t dan uji F. Dari hasil penelitian ini adalah bahwa secara simultan ROE, EPS dan DER berpangruh signifikan terhadap harga saham. Sedangkan secara parsial, hanya ROE dan EPS yang berpengaruh signifikan terhadap harga saham sedangkan DER tidak berpengaruh signifikan terhadap harga saham.

Wati dalam Sihombing (2010), melakukan penelitian tentang pengaruh rasio profitabilitas dan rasio leverage terhadap harga saham pada perusahaan manufaktur di BEI. Penelitian ini bertujuan untuk mengetahui: (1) pengaruh yang signifikan antara return on asset terhadap harga saham pada perusahaan manufaktur di $\mathrm{BEI}$; (2) pengaruh signifikan antara return on equity terhadap harga saham pada perusahaan manufaktur di BEI; (3) pengaruh signifikan antara debt to equity ratio terhadap harga saham pada perusahaan manufaktur di BEI; (4) pengaruh yang signifikan secara bersama-sama antara return on asset, return on equity, dan debt to equity ratio terhadaphargasaham pada perusahaanmanufaktur di BEI. Metode pengumpulan data dengan cara mengumpulkan data dari studi pustaka dan lainlain. Teknis analisis data menggunakan analisis regresi linier berganda, uji-t dan uji F. Dari hasil penelitian ini adalah bahwa secara simultan, rasio profitabilitas dan leverage mempengaruhi harga saham. Sedangkan secara parsial, hanya return on equity asset dan debt to equity ratio yang memiliki pengaruh positif terhadap harga saham 
pada perusahaan manufaktur di BEI.

Dari hasil penelitian-penelitian di atas diperoleh adanya perbedaan hasil penelitian yang dilakukan oleh peneliti terdahulu. Hasil penelitian yang telah dipaparkan diatas dapat dijadikan permasalahan dalam penelitian ini. Dengan melihat hasil penelitian tersebut, maka dapat dibuat rumusan masalah sebagai berikut: (1) Adakah pengaruh antara return on equity terhadap harga saham pada perusahaan consumer goods?; (2) Adakah pengaruh antara net profit margin terhadap harga saham pada perusahaan consumer goods?; (3) Adakah pengaruh antara debt to equity ratio terhadap harga saham pada perusahaan consumer goods?; (4) Adakah pengaruh antara earning per share terhadap harga saham pada perusahaan consumer goods?

\section{REVIEW LITERATUR DAN HIPOTESIS}

Pengukuran kinerja didefinisikan sebagai "perfoming measurement" yaitu kualifikasi dan efisiensi perusahaan atau segmen atau keefektifan dalam pengoperasian bisnis selama periode akuntansi. Dengan demikian pengertian kinerja adalah suatu formal yang dilaksanakan perusahaan untuk mengevaluasi efisien dan efektivitas dari aktivitas perusahaan yang telah dilaksanakan pada periode waktu tertentu (Hanafi dalam Sihombing, 2010).

Informasi kinerja perusahaan dapat digunakan sebagai pertimbangan bagi para investor untuk memutuskan apakah mereka akan menanamkan modal mereka atau tidak. $\mathrm{Hal}$ tersebut pastinya dengan melihat baik tidaknya kinerja keuangan perusahaan.

Untuk mengukur kinerja keuangan Menurut Munawir dalam Sihombing (2010), menyatakan bahwa kinerja keuangan perusahaan adalah:

a. Mengetahui tingkat likuiditas

Likuiditas menunjukkan kemampuan suatu perusahaan untuk memenuhi kewajiban keuangan yang harus segera diselesaikan pada saat ditagih.

b. Mengetahui tingkat solvabilitas

Menunjukkan kemampuan perusahaan untuk memenuhi kewajiban keuangannya apabila perusahaan tersebut dilikuidasi, baik keuangan jangka pendek maupun jangka panjang.

c. Mengetahui tingkat rentabilitas

Rentabilitas atau yang sering disebut dengan profitabilitas menunjukkan kemampuan perusahaan untuk menghasilkan laba selama periode tertentu.

d. Mengetahui tingkat stabilitas

Menunjukkan kemampuan perusahaan untuk melakuan usahanya dengan stabil, yang diukur dengan mempertimbangkan kemampuan perusahaan untuk membayar hutang-hutangnya serta membayar beban bunga atas hutang-hutangnya tepat pada waktunya.

Menurut Harahap (1998), laporan keuangan adalah media yang paling penting untuk menilai prestasi dan kondisi ekonomis suatu perusahaan. Pada tahap pertama seorang analisis tidak akan mampu melakukan pengamatan langsung ke suatu perusahaan. Dan seandainya dilakukan, ia pun tidak akan dapat mengetahui banyak tentang situasi perusahaan. Oleh karena itu yang paling penting adalah media laporan keuangan. Tujuan laporan keuangan dalam Prinsip Akuntansi Indonesia (1984), menyatakan bahwa tujuan laporan keuangan adalah (Harahap, 1998): (1) Untuk memberikan informasi keuangan yang dapat dipercaya mengenai aktiva dan kewajiban serta modal suatu perusahaan; (2) Untuk memberikan informasi yang dapat dipercaya mengenai perubahan dalam aktiva netto (aktiva dikurangi kewajiban) suatu perusahaan yang timbul dari kegiatan usaha dalam rangka memperoleh laba; (3) Untuk memberikan informasi keuangan yang membantu para pemakai laporan di dalam menaksir potensi perusahaan dalam menghasilkan laba; (4) Untuk 
memberikan informasi penting lainnya mengenai perubahan dalam aktiva dan kewajiban suatu perusahaan, seperti informasi mengenai aktivitas pembiayan investasi; (5) Untuk mengungkapkan sejauh mungkin informasi lain yang berhubungan dengan laporan keuangan yang relevan untuk kebutuhan pemakai laporan, seperti informasi mengenai kebijakan akuntansi yang dianut perusahaan.

Menurut Harahap (1998:), kekuatannya sebagai informasi untuk tujuan pemakai umum yang dipercayai pada saat yang sama juga mengandung kelemahan. Pengertian pasar modal secara umum menurut keputusan Menteri Keuangan RI No. 1548/KMK/90, tentang peraturan pasar modal adalah suatu sistem keuangan yang terorganisasi, termasuk didalamnya adalah bank-bank komersial dan semua lembaga perantara di bidang keuangan, serta keseluruhan surat-surat berharga yang beredar (Sunariyah dalam Raharjo, 2005).

Pasar modal dapat menjalankan dua fungsi utama (Ninik dan Anoraga dalam Jamhari, 2009) yaitu:

a. Fungsi Ekonomi

Pasar ekonomi menyediakan fasilitas untuk memindahan dana dari pihak yang mempunyai kelebihan dana (lender) kepihak yang memerlukan dana (barrower).

b. Fungsi Keuangan

Dalam hal ini pasar modal menyediakan dana yang diperlukan oleh para borrower, oleh para lender tanpa harus terlibat langsung dalam kepemilikan aktiva riil yang diperlukan untuk investasi tersebut.

Instrumen pasar modal dalam konteks praktis lebih banyak dikenal dengan sebutan sekuritas. Sekuritas (securities), atau juga disebut efek atau surat berharga, merupakan aset finansial (financial asset) yang menyatakan klaim keuangan (Tandelilin, 2010).

Analisis keuangan yang mencakup analisis rasio keuangan, analisis kelemahan dan kekuatan di bidang finansial akan sangat membantu dalam menilai prestasi manajemen masa lalu dan prospeknya di masa datang (Sartono, 2001). Adapaun jenis-jenis rasio keuangan menurut Hanafi dan Halim dalam Sihombing (2010), rasio keuangan dibagi menjadi lima kelompok bagian, yaitu:

a. Rasio Likuditas

Rasio likuiditas menurut Horne dan Wachowicz (2005) adalah "rasio yang mengukur kemampuan perusahaan untuk memenuhi kewajiban jangka pendeknya". Ada beberapa macam rasio keuangan, antara lain: current ratio, acid test ratio, cash ratio, dan net working capital.

b. Rasio Leverage

Rasio leverage (rasio utang) menurut Horne dan Wachowicz (2005) adalah "rasio yang menunjukkan sejauh mana perusahaan dibiayai oleh utang". Ada beberapa macam rasio leverage, antara lain: debt ratio, debt to equity ratio, long term debt to equity, dan time interested earned.

c. Rasio Aktivitas

Rasio Aktivitas (activity ratio) menuru Horne dan Wachowicz (2005) adalah "rasio yang mengukur seberapa efektif perusahaan menggunakan berbagai aktivanya". Ada beberapa macam rasio aktivitas, antara lain: total aset turnover, account receivable turnover, fixed asset turnover, inventory turnover, average collection period, dan day's sales in inventory.

d. Rasio Profitabilitas

Rasio profitabilitas menurut Horne dan Wachowicz (2005) adalah "rasio yang menghubungkan laba dari penjualan dan investasi". Ada beberapa macam rasio profitabilitas, antara lain: gross profit margin, net profit margin, return on asset, return on equity, dan basic earning power. 
e. Rasio Pasar

Rasio pasar adalah rasio yang menunjukkan bagian dari laba perusahaan, deviden, dan modal yang dibagikan pada setiap saham (Fakhruddin dan Hadianto, 2001). Ada beberapa macam rasio pasar, antara lain: dividen yield, earning per shar, dividen payout ratio, price earning ratio, dan price to book value.

Harga saham merupakan nilai suatu saham yang mencerminkan kekayaan perusahaan yang mengeluarkan saham tersebut (Sihombing, 2010).

Untuk menentukan harga saham terdapat dua pendekatan, yaitu:

a. Analisis Fundamental

Analisis fundamental memiliki asumsi dasar bahwa harga saham tidaklah diukur dari standar harga dipasar, melainkan di prediksi terlebih dahulu dengan analisis perusahaan (Husnan dalam Sihombing, 2010).

b. Analisis Teknikal

Analisis teknikal didahului dengan asumsi dasar harga saham terbentuk dari hasil spekulasi (Ghozali dalam Sihombing, 2010). Kegiatan spekulasi tersebut menitik beratkan pada trend yang dibentuk harga saham pada periode yang lalu dan tidak ada hubungannya dengan nilai intrinsik saham.

\section{Hipotesis}

$\mathrm{H}_{1}$ : Return on equity berpengaruh positif terhadap harga saham pada perusahaan consumer goods

$\mathrm{H}_{2}$ : Net profit margin berpengaruh positif terhadap harga saham pada perusahaan consumer goods

$\mathrm{H}_{3}$ : Debt to equity ratio berpengaruh positif terhadap harga saham pada perusahaan consumer goods

$\mathrm{H}_{4}$ : Earning per share berpengaruh positif terhadap harga saham pada perusahaan consumer goods

\section{METODE PENELITIAN}

\section{Populasi dan Sampel}

Populasi dalam penelitian ini adalah perusahaan consumer goods yang telah go publik di Bursa Efek Indonesia. Dalam penelitian ini pengambilan sampel menggunakan metode purposive sampling yaitu pengambilan sampel berdasarkan pertimbangan atau kriteria tertentu. Adapun kriteria pemilihan sampel sebagai berikut: (1) Saham perusahaan aktif diperdagangkan selama periode 2006 sampai dengan 2010; (2) Perusahaan mengeluarkan laporan keuangan selama lima tahun berturut-turut dari tahun 2006 sampai dengan 2010; (3) Ada kelengkapan data laporan yang dipublikasikan sehingga dapat digunakan untuk menghitung variabel yang digunakan dalam penelitian yaitu return on equity, net profit margin, debt to equity ratio, dan earning per share dari tahun 2006-2010.

\section{Jenis Data dan Sumber Data}

Data yang digunakan dalam penelitian ini adalah data sekunder yaitu data yang diperoleh secara tidak langsung, seperti data dari Bursa Efek Indonesia dan literature lainnya yang berhubungan dengan penelitian ini. Data-data yang diperlukan antara lain: (1) Data harga saham penutupan (closing price) akhir tahun perusahaan sampel dari periode tahun 2006-2010; (2) Data return on equity, net profit margin, debt to equity ratio, dan earning per share perusahaan sampel dengan periode waktu penelitian dari tahun 20062010.

\section{Definisi Operasional Variabel}

Berdasarkan permasalahan dan hipotesis yang dikemukakan, maka variabel dependen (terikat) merupakan variabel yang dipengaruhi atau yang menjadi akibat, karena adanya variabel bebas (Sugiyono, 2010). Dalam hal ini, yang menjadi variabel terikat adalah harga saham (Y).

Sedangkan variabel independen (bebas) merupakan variabel yang mempengaruhi atau 
yang menjadi sebab perubahannya atau timbunya variabel dependen (terikat) (Sugiyono. 2010). Dalam hal ini yang menjadi variabel dependen adalah kinerja keuangan yang diwakili oleh rasio-rasio keuangan yaitu return on equity, net profit margin, debt to equity ratio, dan earning per share.

\section{Teknik Analisis Data}

1. Analisis Regresi Linier Berganda

Permasalahan analisis regresi ini digunakan untuk mengetahui seberapa besar pengaruh ROE, NPM, DER, dan EPS terhadap harga saham. Dengan demikian model analisis dapat dinyatakan sebagai berikut:

Keterangan:

$$
Y=\alpha+\beta_{1} X_{1}+\beta_{2} X_{2}+\beta_{3} X_{3}+\beta_{4} X_{4}+\varepsilon
$$

$$
\begin{array}{ll}
\mathrm{Y} & : \text { Harga Saham } \\
\alpha & : \text { Konstanta } \\
\beta_{1} \ldots \beta_{4}: \text { Koefisien Regresi } \\
\mathrm{X}_{1} & : \text { Return On Equity (ROE) } \\
\mathrm{X}_{2} & : \text { Net Profit Margin (NPM) } \\
\mathrm{X}_{3} & : \text { Debt to Equity Ratio (DER) } \\
\mathrm{X}_{4} & : \text { Earning Per Share (EPS) } \\
\varepsilon & : \text { Error }
\end{array}
$$

2. Pengujian Hipotesis (Uji t $)$

Uji $t$ dilakukan untuk mengetahui atau menguji apakah ada pengaruh antara masingmasing variabel independen dengan harga saham secara individu, dengan kriteria penerimaan sebagai berikut:

a) Apabila sign hitung $>\alpha 5 \%$ maka Ho diterima dan Ha ditolak.

b) Apabila sign hitung $<\alpha .5 \%$ maka Ho ditolak dan $\mathrm{Ha}$ diterima.

3. Uji Koefisien Determinasi $\left(\mathrm{R}^{2}\right)$

Pengujian ini dilakukan untuk mengetahui seberapa besar persentase variabel independen terhadap variabel dependen. Besarnya koefisien determinasi berkisar antara 0 sampai 1 .

\section{HASIL PENELITIAN DAN PEMBAHASAN}

\section{Uji Asumsi Klasik}

1. Uji Normalitas

Uji normalitas bertujuan untuk menguji apakah dalam model regresi, data residual memiliki distribusi normal. Jarque-Bera adalah uji statistik untuk mengetahui apakah data distribusi normal.

Tabel 1

\section{Hasil Uji Normalitas}
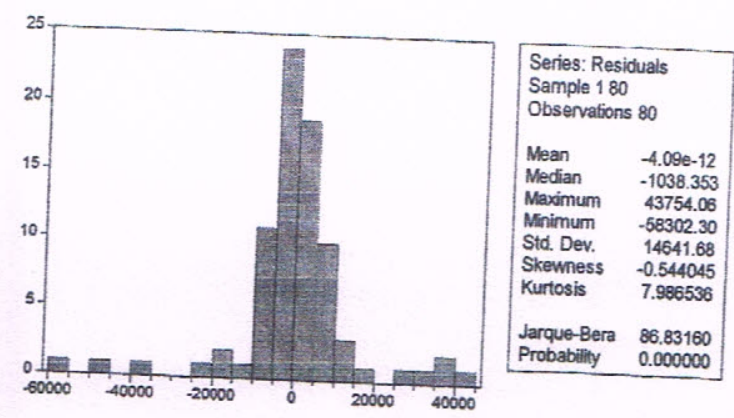

Sumber: Data diolah, 2013

Berdasarkan hasil uji pada tabel diatas dapat disimpulkan bahwa residual persamaan regresi pada penelitian ini mempunyai distribusi tidak normal. Hal ini terlihat pada nilai J-B sebesar 86.831 dengan probabilitas J-B sebesar 0.000 , yang mana lebih kecil dari 0.05 .

\section{Uji Multikolinearitas}

Pengujiàn ini bertujuan untuk mengetahui apakah tiap-tiap variabel bebas saling berhubungan secara linear.

\section{Tabel 2}

Hasil Uji Multikolinearitas

\begin{tabular}{|c|c|c|c|c|}
\hline & ROE & NPM & DER & EPS \\
\hline ROE & 1.000000 & 0.0586056 & 0.692984 & 0.712343 \\
\hline NPM & 0.058606 & 1.000000 & -0.171928 & -0.024093 \\
\hline DER & 0.692984 & -0.171928 & 1.000000 & 0.349075 \\
\hline EPS & 0.712343 & -0.024093 & 0.349075 & 1.000000 \\
\hline
\end{tabular}


Pada pengujian korelasi antar variabel independen terlihat adanya nilai korelasi (derajat keeratan)yang sangatrendah $(<90 \%)$ antarvariabel independen. Ini menunjukkan tidak ada pengaruh yang signifikan dan tidak saling berkorelasi antar variabel independen. Ini menunjukkan tidak adanya gejala multikolinearitas.

3. Uji Heteroskedastisitas

Uji heteroskedatisitas bertujuan menguji apakah dalam model regresi terjadi ketidaksamaan varian dari residual atau pengamatan ke pengamatan lain. Untuk mendeteksi ada atau tidaknya heteroskedastisitas dilakukan dengan cara menggunakan uji White dan uji BreuschPagan-Godfrey.

Tabel 3

Hasil Uji Heteroskedastisitas

\begin{tabular}{|c|r|r|}
\hline & Obs*R-squared & Prob. Chi-Square \\
\hline Uji White & 66.91969 & 0.0000 \\
\hline Uji BPG & 40.53938 & 0.0000 \\
\hline
\end{tabular}

Sumber: Data diolah, 2013

Dari hasil uji terhadap gejala heteroskedastisitas dengan uji White dan uji Breusch-Pagan-Godfrey pada tabel di atas menunjukkan masing-masing nilai probabilitas Chi-Square pada Obs* R-squared lebih kecil daripada 0.05 . Jadi, dalam penelitian ini terlihat adanya masalah heteroskedastisitas.

4. Uji Autokorelasi

Uji autokorelasi bertujuan untuk menguji apakah dalam model regresi linear berganda ada korelasi antara kesalahan pengganggu pada periode $t$ dengan kesalahan periode $\mathrm{t}-1$ (sebelumnya). Jika terjadi korelasi, maka dinamakan ada problem autokorelasi. Pengujian autokorelasi dapat dilakukan dengan menggunakan Breusch-Godfrey.

\section{Tabel 4}

Hasil Uji Autokorelasi

\begin{tabular}{|l|l|l|l|}
\hline Obs*R-squared & 1.371472 & Prob. Chi-Square(2) & 0.5037 \\
\hline
\end{tabular}

Sumber: Data diolah, 2013
Berdasarkan hasil uji Breusch-Godfrey diatas terlihat bahwa nilai probabilitas Chi Square sebesar 0.5037 yang mana lebih besar dari 0.05 (prob.Chi Square $<0.05$ ). Sehingga memperjelas tidak adanya masalah autokorelasi.

\section{Analisis Regresi Linear Berganda}

Berdasarkan hasil uji regresi linear berganda pada tabel 1, maka dapat dibuat persamaan sebagai berikut:

Harga Saham $=7429.880-583.769 *$ ROE + 805.038*NPM - 1172.361*DER + 13.364*EPS $+\mathrm{e}$

Tabel 1

Hasil Uji Regresi Linier Berganda

\begin{tabular}{|c|r|}
\hline Variable & Coefficient \\
\hline C & 7429.880 \\
\hline ROE & 583.769 \\
\hline NPM & 805.038 \\
\hline DER & 1172.361 \\
\hline EPS & 13.364 \\
\hline
\end{tabular}

Dari persamaan regresi linear berganda diatas dapat dijelaskan sebagai berikut:

a. Nilai konstanta sebesar 7429.880 berarti bahwa jika variabel ROE, NPM, DER dan EPS adalah nol maka nilai Harga Saham pada perusahaan consumer goods akan sama dengan nilai konstanta yaitu sebesar 7429.880 .

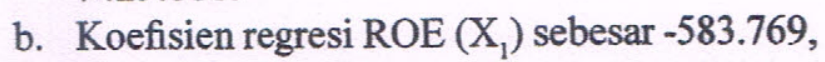
berarti bahwa setiap penurunan satu nilai dari ROE maka akan memberikan kenaikan harga saham pada perusahaan consumer goods sebesar 583.769 poin. Sebaliknya setiap kenaikan satu nilai dari ROE maka akan memberikan penurunan harga saham pada perusahaan consumer goods sebesar $\mathbf{5 8 3 . 7 6 9}$ poin.

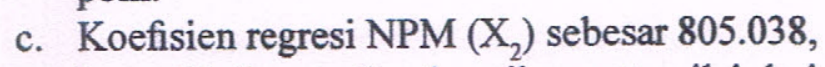
berarti bahwa setiap kenaikan satu nilai dari NPM maka akan memberikan kenaikan harga 
saham pada perusahaan consumer goods sebesar 805.038 poin. Sebaliknya setiap penurunan satu nilai dari NPM maka akan memberikan penurunan harga saham pada perusahaan consumer goods sebesar 805.038 poin.

d. Koefisien regresi DER $\left(\mathrm{X}_{3}\right)$ sebesar-1172.361, berarti bahwa setiap penurunan satu nilai dari DER maka akan memberikan kenaikan harga saham pada perusahaan consumer goods sebesar 1172.361 poin. Sebaliknya setiap kenaikan satu nilai dari DER maka akan memberikan penurunan harga saham pada perusahaan consumer goods sebesar 1172.361 poin.

e. Koefisien regresi EPS $\left(X_{4}\right)$ sebesar 13.364, berarti bahwa satiap kenaikan satu nilai dari EPS maka akan memberikan kenaikan harga saham pada perusahaan consumer goods sebesar 13.364 poin. Sebaliknya setiap penurunan satu nilai dari EPS maka akan memberikan penurunan harga saham pada perusahaan consumer goods sebesar 13.364 poin.

\section{Uji Hipotesis (Uji t)}

Berdasarkan hasil analisis dengan menggunakan program Eviews 6 mengenai pengaruh Return On Equity, Net Profit Margin, Debt to Equity Ratio, dan Earning Per Share secara parsial terhadap harga saham, diperoleh hasil sebagai berikut:

Tabel 2

Hasil Uji t

\begin{tabular}{|c|c|}
\hline Variable & Prob. \\
\hline C & 0.0061 \\
\hline ROE & 0.0000 \\
\hline NPM & 0.0715 \\
\hline DER & 0.4396 \\
\hline EPS & 0.0000 \\
\hline \multicolumn{2}{|c|}{ Sumber $:$ Data diolah 2013} \\
\hline
\end{tabular}

Sumber : Data diolah, 2013 a. Variabel Return On Equity berpengaruh positif signifikan terhadap harga saham, dibuktikan degan nilai prob. < dari alpha $(0.0000<0.05)$, sehingga menerima $\mathrm{Ha}$.

b. Variabel Net Profit Margin tidah berpengaruh signifikan terhadap harga saham, dibuktikan degan nilai prob. $>$ dari alpha $(0.0715>0.05)$, sehingga menerima $\mathrm{HO}$

c. Variabel Debt to Equity Ratio tidak berpengaruh signifikan terhadap harga saham, dibuktikan degan nilai prob. $>$ dari alpha $(0.4396>0.05)$, sehingga menerima H0.

d. Variabel Earning Per Share berpengaruh positif signifikan terhadap harga saham, dibuktikan degan nilai prob. $<$ dari alpha $(0.0000<0.05)$, sehingga menerima Ha.

\section{Koefisien Determinasi $\left(\mathbf{R}^{2}\right)$}

Hasil pengujian koefisien determinasi $\left(R^{2}\right)$ diperoleh nilai $\mathrm{R}$ square sebesar 0.847 . Hal ini menunjukkan bahwa variabel independen Return On Equity (ROE), Net Profit Margin (NPM), Debt to Equity Ratio (DER), dan Earning Per Share (EPS) mampu mempengaruhi perubahan variabel dependen yaitu harga saham sebesar $84.7 \%$ sedangkan sisanya $15.3 \%$ dipengaruhi oleh variabel lain diluar variabel yang digunakan dalam penelitian.

$$
\begin{gathered}
\text { Tabel } 3 \\
\text { Hasil Uji Koefisien Determinasi } \\
\qquad \begin{array}{|c|}
\hline \mathbf{R}^{2} \\
\hline 0.847 \\
\text { Sumber : Data diolah, } 2013
\end{array}
\end{gathered}
$$

\section{KESIMPULAN DAN SARAN}

Dari hasil pengujian hipotesis diperoleh kesimpulan sebagai berikut:

Variabel Return On Equity berpengaruh positif signifikan terhadap harga saham, dibuktikan degan nilai prob. < dari alpha $(0.0000$ $<0.05$ ), sehingga hipotesis diterima.

Variabel Net Profit Margin tidah berpengaruh signifikan terhadap harga saham, 
dibuktikan degan nilai prob. $>$ dari alpha $(0.0715$ $>0.05$ ), sehingga hipotesis ditolak.

Variabel Debt to Equity Ratio tidak berpengaruh signifikan terhadap harga saham, dibuktikan degan nilai prob. $>$ dari alpha $(0.4396$ $>0.05$ ), sehingga hipotesis ditolak.

Variabel Earning Per Share berpengaruh positif signifikan terhadap harga saham, dibuktikan degan nilai prob. $<$ dari alpha $(0.0000$ $<0.05$ ), sehingga hipotesis diterima.

Bagi investor yang ingin berinvestasi dalam bentuk saham dan menyukai keuntungan dari rasio-rasio keuangan ini bisa menggunakan return on equity, net profit margin, debt to equity ratio, dan earning per share untuk memprediksi kemampuan perusahaan untuk menjaga kelangsungan hidup perusahaannya.

Untuk peneliti selanjutnya disarankan menambah variabel-variabel lain yang diperkirakan akan berpengaruh terhadap harga saham, seperti rasio likuiditas yaitu current ratio, cash ratio, rasio profitabilitas yaitu return on asset, dan rasio pasar yaitu deviden payout ratio, price earning ratio. Dan hendaknya menambah periode pengamatan untuk melihat tingkat konsisten hasil penelitian supaya hasilnya lebih akurat dan valid.

\section{DAFTAR PUSTAKA}

Dendawijaya, Lukman. 2005. Manajemen Perbankan Edisi Kedua. Jakarta. Ghalia Indonesia

Fadilla, Afra. 2013. Analisis Pengaruh Cash Position, Debt To Equity Ratio, dan Return On Assets terhadap Devidend Payout Ratio pada Perusahaan Properti yang Terdaftar di Bursa Efek Indonesia. Skripsi. Yogyakarta: Universitas Ahmad Dahlan
Harahap, Sofyan Syafri. 1998. Analisis Kritis atas Laporan Keuangan. Jakarta. PT Raja Grafindo Persada

Ismanto, Deni dan Kusuma Rizky, Desta. 2012. Petunjuk Pratikum Eviews 6. Yogyakarta: Universitas Ahmad Dahlan

Jamhari, Ahmad, 2009. Pengaruh Kinerja Keuangan terhadap Harga Saham Studi pada Perusahaan yang terdaftar di Jakarta Islami Index. Skripsi. Yogyakarta: Universitas Ahmad Dahlan

Prastowo, Dwi dan Rifka Julianty. 2005. Analisis Laporan Keuangan Konsep dan Aplikasi edisi kedua. Yogyakarta: UPP AMP YKPN

Raharjo, Susilo. 2005. Analisa Pengaruh Kinerja Keuangan terhadap Return Saham pada Perusahaan LQ-45 di Bursa Efek Jakarta. Skripsi. Universitas Islam Indonesia

Samsul, Mohammad. 2006. Pasar Modal dan Manajemen Portofolio. Jakarta. Erlangga

Sartono, Agus. 2001. Manajemen Keuangan Teori \& Aplikasi edisi 4. Yogyakarta. BPFE

Sihombing, Yessika C. 2010. Pengaruh Kinerja Keuangan terhadap Harga Saham pada Perushaaan Industri Barang Konsumsi di Bursa Efek Indonesia. Skripsi. Universitas Sumatera Utara

Sugiyono. 2007. Metode Penelitian Bisnis. Bandung. CV. Alfabeta

Tandelilin, Eduardus. 2010. Portofolio \& Investasi Teori \& Aplikasi Edisi Pertama. Yogyakarta. Kanisisus 